\title{
The Development of Evaluation Model for Sustainable Social Enterprises: Focusing on an Application of Social Return on Investment
}

\author{
Dong-Joo Kim ${ }^{1}$ and Yong-Seung $\mathrm{Ji}^{2}$, * \\ 'Department Rehabilitation Studies, Woosuk University, Wanju-gun, \\ Jeollabuk-do, South Korea; ju7055@naver.com \\ ${ }^{2}$ Department Division of Liberal Arts, Woosuk University, Wanju-gun, \\ Jeollabuk-do, South Korea; enerji70@gmail.com
}

\begin{abstract}
Background/objectives: To prepare a plan for the support and management of social enterprise from the viewpoint of government and to establish a method to evaluate social enterprises for sustainability by applying Social Return on Investment (SROI). Methods/statistical analysis: The Delphi first and second surveys for the development of evaluation model for social enterprises using SROI were conducted with 50 social enterprise CEOs and experts. To produce the results of this study, the SPSS 20.0, AMOS 24 and Expert Choice 11 programs were used, and a pairwise comparison was performed to analyse the importance and priority of criteria found in the data and chosen for the present study. Findings: The results of the Delphi and AHP analyses showed that employment was the most important factor in social enterprises, with the highest share of newly hired personnel indicating so. Employment-type social enterprises have the highest priority in terms of employment, income (income increase for vulnerable workers), and community contribution (affordability of social services), whereas the social service type was the preferred option in regards to employment, community contribution, and income (income increase for the vulnerable workers). On the other hand, the mixed type's preference was employment (newly hired personnel), income (income increase of vulnerable workers), employment (social work participants' switch to similar work after contract expiration), and community contribution (affordability of social services). Improvements/ applications: This study makes efforts to form social capital by raising the public's awareness of social value with efficient management through various evaluations of social enterprises and the emergence of various social enterprises. This study also emphasises the need to better understand social enterprises as a multi-scholar and multi-dimensional organisation that includes a multi-faced mechanism of social, economic, and environmental community development, away from understanding social enterprises as a specific business model.
\end{abstract}

Keywords: Social Return on Investment (SROI), Sustainable Social Enterprises, Delphi, AHP

\section{Introduction}

As interest in social enterprises has been rising, the sustainability issue of social enterprise has been strongly raised as the government has demonstrated a strong will to foster social enterprises. As the number of social enterprises is on the rise, there is a need for management and follow-up measures in relation to the efficiency, performance, and goal achievement of social enterprises, and there is a constant question as to whether sustainable societal organisations in a broad sense will have a future. $.^{-}-\underline{6}$ As a measure to secure the sustainability of social enterprises, the government intends to strengthen its monitoring and evaluate the social enterprises through government-led measures. However, the evaluation of social enterprises has been criticised because it does not reflect the positive aspect of social enterprise through financial evaluation.

${ }^{*}$ Author for correspondence 
The ROI (Return on Investment), which is currently being measured in the evaluation system for social enterprises, measures only the economic value added to the economic benefits minus the economic costs. It can be understood as the recovery rate of investment. Future cash flows are expressed as a percentage of investment. This is expressed as the ratio of the present value of the number of returns to the present value of the investment in terms of the enterprise, which is not suitable as an evaluation tool of social enterprise. While the realisation of social objectives is emphasised as an important role of social enterprises, the lack of an accurate evaluation of social enterprises in this regard could not accurately conveyed. This can be seen as compelling a social enterprise to achieve both social goals and realisation of benefits.

In the case of social enterprises in Europe, the study of social enterprises was mainly influenced by the economic ripple effects of social enterprises and their impact on regional development. $-\underline{-11}$ On the basis of this, research on the social value of social enterprises has chosen for its premise the development and use of new evaluation tools specifically to provide an accurate evaluation of social enterprises. The effort to measure the social contribution of social enterprises as a measure of their ROI has indeed begun. Various evaluation methods such as BSC (Balanced Scorecard) and DEA (Data Envelopment Analysis) have been studied for their effectiveness as tools for performance evaluation. Recently, SROI (Social Return on Investment) focused on Robert Enterprise Development Fund (REDF). Subsequently, the value of the said enterprise has begun to rise. $\underline{12}-\underline{17}, \underline{19}-\underline{24}$

The most important goal of social-economic organisations is to increase sustainability, given the nature of social enterprises included in the social economy area. $\underline{25}-\underline{27}$ The social enterprise sustainability criteria are summarised as follows: process and structure, human resources, finance, governance, performance measurement, and market recognition. $\underline{28}-\underline{30}$ In particular, SROI, as a measure of performance measurement, is a social concept applied to the measurement of economic ROI and is intended to measure the social added value of social enterprise and the extent to which it is reflected on its performance.

The concept of SROI has been mostly unfamiliar and has not been applied at the national level. The evaluation of the social enterprise up to now has been carried out by the Ministry of Labor, and the evaluation of the concept of ROI has excluded the 'social enterprise' component. In the early stage of social enterprise, the lack of understanding about social enterprises' ROI can be said to be one of the main causal factors that may have led to the erosion of social enterprises' value. Therefore, it is necessary to provide sustainability to social enterprise through accurate assessment of social enterprises' ROI and provide opportunities for both the social enterprise and its target community to assimilate through publicity. Even the government is only conducting research in the direction of SROI, and currently there is no ongoing discussions on how to apply SROI to help social enterprises sustain themselves in the long run. This study is needed to prepare a plan for the support and management of social enterprises from the viewpoint of the government. The purpose of this study is to establish a method to evaluate Korean social enterprises by applying SROI.

\section{Materials and Methods}

\subsection{Research Target and Collecting Data}

In this study, the Delphi first and second surveys for the development of evaluation model for social enterprises in Korea using SROI were conducted from September 19 to 27, 2017, with 50 social enterprise CEOs and experts. A total of 29 respondents from the second survey were interviewed by 11 CEOs of social enterprises, 1 public employee related to social enterprises, 12 college professors, and 5 social enterprise experts. They were interviewed after emailing to them the structured questionnaires prepared for collecting data.

\subsection{Research Methods}

In order to carry out the research, we first reviewed the literature on SROI and AHP (Analytic Hierarchy Process). Through literature review, we came to understand the contents of existing research, which indirectly strengthened the possibility of applying it to social enterprise. Next, we reviewed the application process of SROI and analysed the exiting SROI cases. Through case analysis, evaluation indicators were secured by division and the evaluation indicators sorted by category. The sectoral pool of evaluation index on social enterprise was secured through a literature review of the existing SROI. Delphi survey was conducted on the pools chosen for each sector, and key indicators were selected through additional evaluation indicators and additional processes. Finally, AHP was used to calculate inter-sector weights. In addition, interviews with the CEOs of social 
enterprises revealed a higher possibility of application of SROI as the inputs gathered from the participants showed specific problems and their solutions in relation to the application of SROI.

\subsection{Data Analysis}

In this study, the lowest level was constructed around the indicator items derived through Delphi, and the homogeneous element was arranged around the lower level. First, in the first Delphi survey, items were selected based on the average responsiveness of the respondents to select areas and items suitable for evaluating the economic value of social enterprises. Second, the second Delphi survey re-evaluated the appropriateness of items chosen for each social value area and sub-items in order to verify social values and indicators modified by the first Delphi survey. At this time, the panel was asked to refer to the results of the first survey. In addition to evaluating the role areas and subcategories, comments were added for each area and item. Third, social value areas and indicators of social enterprises modified through this process were finally identified. Finally, the first and second Delphi surveys were used to calculate the indicators and weights were selected for them. Weights were calculated using AHP to assess the most important factors and weights to evaluate specific gravity in social enterprises. To produce the results of this study, the SPSS 20.0, AMOS 24, and Expert Choice 11 programs were used, and a pairwise analysis of comparison was performed to analyse the importance and priority of items chosen. The level $\alpha$ to which the Type I error was made was set at 0.5 .

\section{Results}

\subsection{Characteristics of the Subjects}

According to the characteristics of respondents based on the results of the final survey, $82.8 \%$ were male ( 24 persons) and $17.2 \%$ were female (5 persons). In relation to age criterion, $17.2 \%$ were 30 to 39 years old (5 persons), $55.2 \%$ were 40 to 49 years old (16 persons), and $27.6 \%$ were over 50 years old (8 persons). Last, in the 'work' category, 12 were college professors $(41.4 \%), 11$ were social enterprise workers (37.9\%), 1 person was a public employee of a social enterprise (3.4\%), and 5 others were categorised as social enterprise experts (17.2\%). In general, they are operating social enterprises or are experts in their 40s. In terms of education, the percentage of those who attended and completed graduate school was the highest, followed by that of college graduates, with more opportunities for starters toward higher education. In terms of occupations, the number of workers in social enterprises was the highest, followed by other social enterprise experts, university professors, and public employee (Table 1).

\subsection{Characteristics of Correlation among Major Variables}

In order to verify the revised social value domains and indicators used in the first Delphi survey, the second Delphi survey re-evaluated the suitability of each social value domain and item. The panel added comments on each area and item, as well as evaluated social value domain and items. Finally, the removed or corrected items were identified for the revised social value domain and indicators of the social enterprise. The results of the analysis of the validity and reliability of the panel's evaluation of items of the second Delphi survey are presented as follows.

\subsubsection{Social Value Domains}

In this study, to verify the validity of the evaluation items for the second survey, an estimation was made by using the correlation between individual items and the total score, and the reliability of the items was calculated by Cronbach's a coefficient to estimate the degree of agreement between the items. The results are shown in Table 2. The correlation between the items and the total scores in the social value domain was $0.426 \sim 0.711$. According to the correlation coefficient between the total score and each item, the 7th item of 'self-esteem recovery and increase' did not show a statistically significant correlation with the total score. The 1st item of 'job creation', the 9th item of 'protection for safety', and the 10 th item of 'the government's budget reduction' were significant at the significance level of 0.05 . The 10 items of the savings were significant at the significance level of 0.05 , the 2 nd item of 'increase of worker's income', the 3rd item of 'increase of income of workers'/service users' family', the 4th item of 'transitional job', the 5th item of 'enhancing worker's job ability', and the 6th item of 'strengthening social network and participants' selfdevelopment', the 8th item of 'community contribution', and the 11th item of 'improvement of health level' were 
Table 1. Characteristics of the subjects

\begin{tabular}{|c|c|c|c|c|c|}
\hline \multirow{2}{*}{ Variables } & \multirow{2}{*}{ Category } & \multicolumn{2}{|c|}{$1^{\text {st }}$ survey } & \multicolumn{2}{|c|}{$2^{\text {nd }}$ survey } \\
\hline & & Frequency & Percentage & Frequency & Percentage \\
\hline \multirow{2}{*}{ Gender } & Male & 28 & 82.4 & 24 & 82.8 \\
\hline & Female & 6 & 17.6 & 5 & 17.2 \\
\hline \multirow{3}{*}{ Age } & $30-39$ years old & 5 & 14.7 & 5 & 17.2 \\
\hline & 40-49 years old & 19 & 55.8 & 16 & 55.2 \\
\hline & Over 50 years old & 10 & 29.4 & 8 & 27.6 \\
\hline \multirow{3}{*}{$\begin{array}{l}\text { Final Academic } \\
\text { Status }\end{array}$} & Under college & 3 & 8.8 & 1 & 3.4 \\
\hline & University & 9 & 26.5 & 8 & 27.6 \\
\hline & Graduate school (attending) & 22 & 64.7 & 20 & 69.0 \\
\hline \multirow{5}{*}{ Jobs } & College professors & 13 & 38.2 & 12 & 41.4 \\
\hline & Social enterprise workers & 14 & 41.2 & 11 & 37.9 \\
\hline & $\begin{array}{l}\text { Public employee related to social } \\
\text { Enterprise }\end{array}$ & 1 & 2.9 & 1 & 3.4 \\
\hline & $\begin{array}{l}\text { Other experts related social } \\
\text { enterprise }\end{array}$ & 6 & 17.6 & 5 & 17.2 \\
\hline & Total & 34 & 100.0 & 29 & 100 \\
\hline
\end{tabular}

Table 2. Validity and reliability of social value domains in social enterprises

\begin{tabular}{|c|c|c|c|c|c|c|}
\hline \multirow{2}{*}{$\begin{array}{l}\text { Item } \\
\text { number }\end{array}$} & \multirow{2}{*}{ Item contents } & \multicolumn{4}{|c|}{$2^{\text {nd }}$ survey } & \multirow{2}{*}{ Remarks } \\
\hline & & M & SD & Corr. & Cronbach's & \\
\hline 1 & Job Creation & 4.61 & .497 & $.426^{*}$ & .718 & \\
\hline 2 & Workers' Income Increase & 4.18 & .612 & $.711^{* *}$ & .675 & \\
\hline 3 & $\begin{array}{l}\text { Income Increase of Worker/Service } \\
\text { Users' Family }\end{array}$ & 4.04 & .637 & $.706^{\star \star}$ & .675 & \\
\hline 4 & Transitional Job & 3.89 & .629 & $.489^{* *}$ & .714 & \\
\hline 5 & Enhancing Workers' Job Ability & 3.89 & .629 & $.622^{* *}$ & .691 & \\
\hline 6 & $\begin{array}{l}\text { Strengthening Social Network \& } \\
\text { Participant Self-Development }\end{array}$ & 3.82 & .548 & $.584^{* *}$ & .697 & \\
\hline 7 & Self-esteem Recovery \& Increase & 3.72 & .744 & .280 & .759 & deleted \\
\hline 8 & Community Contribution & 4.61 & .567 & $.521^{* *}$ & .707 & \\
\hline 9 & Protection for Safety & 3.39 & .567 & $.441^{\star}$ & .719 & \\
\hline 10 & Government's Budget Reduction & 3.82 & .612 & $.318^{*}$ & .726 & \\
\hline \multirow[t]{2}{*}{11} & Improvement of Health Level & 3.82 & .723 & $.646^{* *}$ & .688 & \\
\hline & & \multicolumn{5}{|c|}{ Total Cronbach's alpha $=\mathbf{0 . 7 2 8}$} \\
\hline
\end{tabular}

significant at the level of 0.01 . Also, the Cronbach's $\alpha$, which is a reliability coefficient indicating the agreement between the evaluation items, was 0.728 , showing high reliability. In addition, since there were no sub-items related to 'strengthening social networks' in the areas of 'strengthening social networks and participant selfdevelopment', we also suggested opinions on index correction by 'participant self-development'. 


\subsubsection{Items of Social Enterprises' Measurement}

The correlation between the items and the total score of the social value index was $0.256 \sim 0.812$. As a result of the correlation coefficient between total score and each item, the 10th item of increasing self-esteem through vocational activities' did not show a statistically significant correlation with total score. The 1st item of 'newly hired personnel', the 2nd item of 'income increase for vulnerable workers', the 3rd item of 'income increase of workers/service users' family through economic activities', the 6th item of 'degree of technical competence through vocational activities', the 9th item of 'providing social training for workers', the 14th item of 'budget reduction through consignment management of social welfare', and the 17th item of 'reduction of family's care cost' were significant at the significance level of 0.05 . The 4 th item of 'social work participants' switch to similar work after contract expiration', the 5th item of 'certification through vocational activities', the 8th item of 'providing cultural programs for workers', the 11th item of 'affordable social services', the 12th item of 'free provision of the social services', the 13th item of 'reduction of safety accidents in social enterprises', the 14 th item of 'budget reduction through consignment management of social welfare services', and the 15th item of 'reduction of use of tertiary care institutions' were significantly higher at the level of 0.01 . Also, the value of Cronbach's $\alpha$, which is the coefficient of confidence indicating the degree of agreement among the evaluation items, was 0.863 , showing high reliability. However, there was an increase in Cronbach's a value to 0.866 that occurred because of the removal of the 10th item of 'increasing self-esteem through vocational activities'. Therefore, it was considered appropriate to exclude this item (Table 3).

\subsection{AHP System Configuration}

In this study, the lowest level was constructed around the indicator items derived through Delphi, and the homogeneous elements were arranged around the constructed level. The next level was arranged based on the relationship between the area of social value evaluation derived from Delphi and the lower level. At the top level, the elements are clustered and arranged around the elements arranged at the middle level. The first-level hierarchical structure was based on the relationship between levels, $\underline{31}$ centred on clusters of similar elements. The AHP system configuration was organised through advices provided by experts, such as researchers, AHP experts, and academia, based on the hierarchies as shown in Figure 1.

\subsection{Estimation of Weights by Sector through AHP Analysis}

In the AHP process of analysis of importance, only the response data that were identified as less than 0.2 as determined through the consistency ratio among the responses of the AHP survey subjects were validated and used for AHP data analysis. The consistency is a criterion for verifying the consistency of responses in the AHP analysis carried out for making pairwise comparisons, and the consistency index (CI) and consistency ratio (CR) can be obtained by the following equation.

$$
\text { Consistency Index }(\mathrm{CI})=\frac{\lambda \max -n}{n-1}, \lambda \max \geq n
$$

Consistency Ratio $(\mathrm{CR})=\left(\frac{C I}{\text { Random }}\right.$ Consistency Index $) \times 100 \%$

This equation was used to determine the consistency of respondents for Level I and Level II. In AHP, there are two main ways to combine group estimates. In other words, it can be divided into 'group evaluation method' and 'numeric integration method'. $\underline{13}$ In this study, we used arithmetic mean to carry out the commonly used numerical integration and integrated weight estimation methods.

As a result of the AHP evaluation, the most important factor in social enterprises was employment, which had the highest proportion of newly hired personnel. In employment type, the proportion of newly hired personnel was $55.9 \%, 23.4 \%$ in social service, and $34.5 \%$ in mixed type. Employment-type social enterprises are in the order of employment, income (income increase for vulnerable workers), and community contribution (affordable social services), whereas social service-type social enterprises have been marked for features such as employment, community contribution, and income 
Table 3. Validity and reliability of social value items in social enterprises

\begin{tabular}{|c|c|c|c|c|c|c|}
\hline \multirow{2}{*}{$\begin{array}{l}\text { Item } \\
\text { number }\end{array}$} & \multirow[b]{2}{*}{ Item contents } & \multicolumn{4}{|c|}{$2^{\text {nd }}$ survey } & \multirow[b]{2}{*}{ Remarks } \\
\hline & & $\mathbf{M}$ & SD & Corr. & Cronbach's & \\
\hline 1 & Newly Hired Personnel & 4.44 & .641 & $.408^{*}$ & .861 & \\
\hline 2 & Income Increase for Vulnerable Workers & 4.33 & .555 & $.256^{*}$ & .858 & \\
\hline 3 & $\begin{array}{l}\text { Income Increase of Workers'/Service } \\
\text { Users' Family Through Economic } \\
\text { Activities }\end{array}$ & 4.15 & .602 & $.484^{*}$ & .854 & \\
\hline 4 & $\begin{array}{l}\text { Social Work Participants' Switch to Similar } \\
\text { Work After Contract Expiration }\end{array}$ & 4.04 & .898 & $.693^{* *}$ & .853 & \\
\hline 5 & $\begin{array}{l}\text { Certification Through Vocational } \\
\text { Activities }\end{array}$ & 4.07 & .730 & $.578^{* *}$ & .857 & \\
\hline 6 & $\begin{array}{l}\text { Degree of Technical Competence Through } \\
\text { Vocational Activities }\end{array}$ & 4.26 & .526 & $.473^{*}$ & .860 & \\
\hline 7 & Family Counselling \& Free Education & 3.93 & .874 & $.672^{* *}$ & .852 & \\
\hline 8 & Providing Cultural Programs for Workers & 4.22 & .801 & $.808^{\star *}$ & .840 & \\
\hline 9 & Providing Social Training for Workers & 3.85 & .718 & $.439^{*}$ & .857 & \\
\hline 10 & $\begin{array}{l}\text { Increasing Self-esteem Through } \\
\text { Vocational Activities }\end{array}$ & 4.07 & .651 & .088 & .866 & Deleted \\
\hline 11 & Affordable Social Services & 4.41 & .572 & $.555^{\star *}$ & .855 & \\
\hline 12 & Free Provision of Social Services & 4.04 & .706 & $.422^{* *}$ & .857 & \\
\hline 13 & $\begin{array}{l}\text { Reduction of Safety Accidents in Social } \\
\text { Enterprises }\end{array}$ & 3.59 & .797 & $.633^{* *}$ & .854 & \\
\hline 14 & $\begin{array}{l}\text { Budget Reduction Through Consignment } \\
\text { Management of Social Welfare Services }\end{array}$ & 3.89 & .698 & $.397^{*}$ & .860 & \\
\hline 15 & $\begin{array}{l}\text { Reduction of Use of Tertiary Care } \\
\text { Institutions }\end{array}$ & 3.96 & .898 & $.812^{\star *}$ & .837 & \\
\hline 16 & Reduction of Hospitalisation Days & 3.37 & .742 & $.464^{*}$ & .860 & \\
\hline \multirow[t]{2}{*}{17} & Reduction of Family's Care Cost & 3.37 & .742 & $.424^{*}$ & .859 & \\
\hline & & \multicolumn{5}{|c|}{ Total Cronbach's alpha $=\mathbf{0 . 8 6 3}$} \\
\hline
\end{tabular}

(income increase for vulnerable workers). On the other hand, mixed (employment- and social servicetype) social enterprises were analysed for items such as employment (newly hired personnel), income (increased income of vulnerable workers), employment (social work participants' switch to similar work after contract expiration), and community contribution (affordable social services), and the findings in this regard are presented in Table 4. Overall, employment, community contribution, and income were considered as the most important factors. Therefore, items such as employment, income, and community contribution could be used to assess social enterprises.

\section{Discussion}

\subsection{Social Enterprises Evaluation Model Using SROI}

The following model can be used for the evaluation of sustainable social enterprises presented in this study. Absolute value can be assessed through SROI, but there 


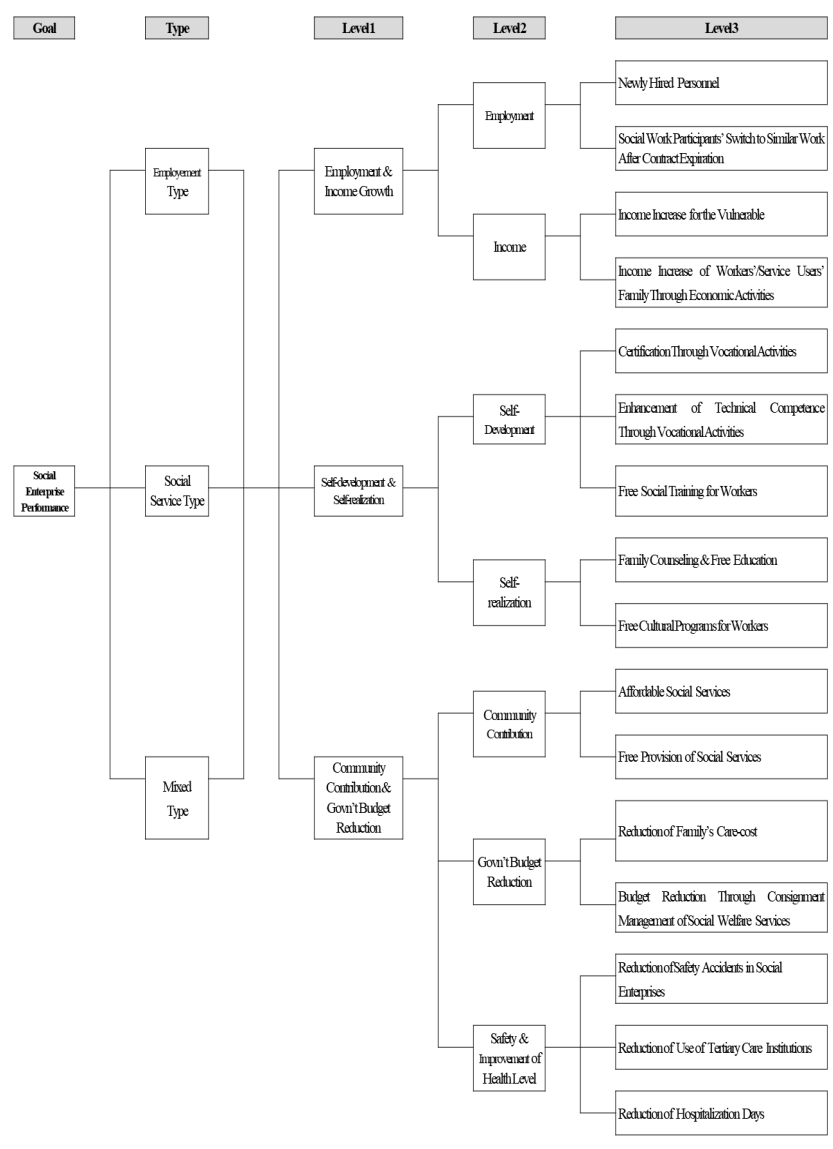

Figure 1. AHP system.

is a limit to assessing relative value, so it can be used as an indicator for evaluation. By describing both the absolute value and the relative value of a social enterprise, a comparison can be made between them.

\subsection{Diagnostic Kit on Management}

For continuous monitoring of social enterprises, an assessment of the situation of social enterprises should be carried out. However, these tasks cannot be utilised frequently because of the difficulty of collecting and evaluating data. However, by using the above AHP, a diagnostic kit on the management of social enterprises can be created by using only a few important indicators, and a list of companies that need to be managed; the evaluations for these companies are made more frequently than for other companies. Although social enterprises have different weights depending on their type, AHP results show that employment, income, and community contributions are the most important at the second level. A diagnostic kit on management as shown in Table 5 below has been prepared using the weighted percentages of the AHP results for three sectors at Level 2 and six sectors at Level 3.

\section{Conclusion}

Major conclusions from this research as follows: First, in order to prepare a plan for evaluating social enterprises by applying SROI, an SROI application evaluation model was proposed. In order to prepare the evaluation indicators, the Delphi survey was used to derive the evaluation index items suitable for the social enterprise according to the experts interviewed in the first and second surveys. The weights were calculated through AHP analysis. The results of the Delphi and AHP analysis showed that employment was the most important factor in social enterprises in Korea, with the highest share of newly hired personnel. Employmenttype social enterprises have the highest priority in terms of employment, income (income increase for vulnerable workers), and community contribution (affordability of social services), whereas the priority of factors observed in social service type was in the order of employment, community contribution, and income (income increase for the vulnerable workers). On the other hand, in the mixed type priority was in the order of employment (newly hired personnel), income (income increase of vulnerable workers), employment (social work participants' switch to similar work after contract expiration), and community contribution (affordability of social services).

Second, this model can be used for the evaluation of social enterprises in general and the evaluation of the social enterprises certified by the Ministry of Employment and Labor in Korea in particular. The evaluation of social enterprises by applying SROI, as discussed in this study, will enable a more accurate valuation of social enterprises and provide clear results because of the evaluation indicators that were created based on a quantitative evaluation. It can also be provided as a basis for assessing the interest level of individuals, companies, and investment funds in investing in social enterprises that are common in developed countries. In addition, the findings presented here can be used as a basis to develop ideas and policies and programs that aim to promote the importance of social enterprises through accurate evaluation of their socioeconomic value.

In summary, although there are various advantages and disadvantages for each evaluation in measuring the performance of social enterprises, it is necessary to 
Table 4. Items and weights by type of social enterprises

\begin{tabular}{|c|c|c|c|c|c|c|c|c|}
\hline \multicolumn{3}{|l|}{ Social value } & \multicolumn{2}{|c|}{ Employment-type } & \multicolumn{2}{|c|}{ Social service-type } & \multicolumn{2}{|c|}{ Mixed-type } \\
\hline Level 1 & Level 2 & Level 3 & Weights & Rank & Weights & Rank & Weights & Rank \\
\hline \multirow{4}{*}{$\begin{array}{l}\text { Employment \& } \\
\text { Income Increase }\end{array}$} & \multirow[b]{2}{*}{ Employment } & Newly Hired Personnel & .559 & 1 & .234 & 1 & .345 & 1 \\
\hline & & $\begin{array}{l}\text { Social Work } \\
\text { Participants' Switch } \\
\text { to Similar Work After } \\
\text { Contract Expiration } \\
\end{array}$ & .109 & 2 & .125 & 2 & .093 & 3 \\
\hline & \multirow[b]{2}{*}{ Income } & $\begin{array}{l}\text { Income Increase for } \\
\text { Vulnerable Workers }\end{array}$ & .088 & 3 & .076 & 5 & .132 & 2 \\
\hline & & $\begin{array}{l}\text { Income Increase of } \\
\text { Workers'/Service } \\
\text { Users' Family Through } \\
\text { Economic Activities }\end{array}$ & .019 & 8 & .043 & 10 & .058 & 5 \\
\hline \multirow{5}{*}{$\begin{array}{l}\text { Self- } \\
\text { development \& } \\
\text { Self-esteem }\end{array}$} & \multirow{3}{*}{$\begin{array}{l}\text { Self- } \\
\text { development }\end{array}$} & $\begin{array}{l}\text { Certification Through } \\
\text { Vocational Activities }\end{array}$ & .030 & 6 & .045 & 9 & .058 & 6 \\
\hline & & $\begin{array}{l}\text { Technical Competence } \\
\text { Through Vocational } \\
\text { Activities }\end{array}$ & .035 & 5 & .066 & 6 & .055 & 7 \\
\hline & & $\begin{array}{l}\text { Providing Social } \\
\text { Training for Workers }\end{array}$ & .016 & 10 & .042 & 11 & .027 & 11 \\
\hline & \multirow{2}{*}{ Self-esteem } & $\begin{array}{l}\text { Family Counselling \& } \\
\text { Free Education }\end{array}$ & .012 & 12 & .049 & 7 & .038 & 9 \\
\hline & & $\begin{array}{l}\text { Providing Cultural } \\
\text { Programs for Workers }\end{array}$ & .016 & 9 & .047 & 8 & .032 & 10 \\
\hline \multirow{7}{*}{$\begin{array}{l}\text { Community } \\
\text { Contribution \& } \\
\text { Government's. } \\
\text { Budget } \\
\text { Reduction }\end{array}$} & \multirow{2}{*}{$\begin{array}{l}\text { Community } \\
\text { Contribution }\end{array}$} & $\begin{array}{l}\text { Affordable Social } \\
\text { Services }\end{array}$ & .049 & 4 & .082 & 4 & .069 & 4 \\
\hline & & $\begin{array}{l}\text { Free Provision of Social } \\
\text { Services }\end{array}$ & .025 & 7 & .087 & 3 & .040 & 8 \\
\hline & \multirow[b]{2}{*}{$\begin{array}{l}\text { Government's } \\
\text { Budget } \\
\text { Reduction }\end{array}$} & $\begin{array}{l}\text { Reduction of Family's } \\
\text { Care Cost } \\
\end{array}$ & .014 & 11 & .034 & 12 & .015 & 13 \\
\hline & & $\begin{array}{l}\text { Budget Reduction } \\
\text { Through Consignment } \\
\text { Management of Social } \\
\text { Welfare Services } \\
\end{array}$ & .011 & 13 & .030 & 13 & .018 & 12 \\
\hline & \multirow{3}{*}{$\begin{array}{l}\text { Safety \& } \\
\text { Increase } \\
\text { Health Level }\end{array}$} & $\begin{array}{l}\text { Reduction of Safety } \\
\text { Accidents in Social } \\
\text { Enterprises }\end{array}$ & .008 & 14 & .016 & 14 & .011 & 14 \\
\hline & & $\begin{array}{l}\text { Reduction of Use } \\
\text { of Tertiary Care } \\
\text { Institutions }\end{array}$ & .005 & 15 & .013 & 15 & .007 & 15 \\
\hline & & $\begin{array}{l}\text { Reduction of } \\
\text { Hospitalisation Days }\end{array}$ & .004 & 16 & .011 & 16 & .005 & 16 \\
\hline
\end{tabular}

choose a valuation method that is commonly used, if the purpose of valuation is to manage the social enterprises. Although social enterprises are generally in their infancy, they show more socioeconomic value than government subsidies, even though they are not exactly valued in terms of providing social services or employment. This social value is expected to increase as social enterprises' service stability improves over time. 
Table 5. Diagnostic kit on management by type of social enterprises

\begin{tabular}{|c|c|c|c|c|c|c|}
\hline \multicolumn{3}{|c|}{ Social value \& items } & \multirow[b]{2}{*}{ Formula } & \multicolumn{3}{|l|}{ Weights } \\
\hline Level 1 & Level 2 & Level 3 & & $\begin{array}{l}\text { Employment- } \\
\text { type }\end{array}$ & $\begin{array}{l}\text { Social } \\
\text { Service-type }\end{array}$ & Mixed-type \\
\hline \multirow{4}{*}{$\begin{array}{l}\text { Employment } \\
\text { \& Income } \\
\text { Increase }\end{array}$} & & $\begin{array}{l}\text { Newly } \\
\text { Hired } \\
\text { Personnel }\end{array}$ & $\begin{array}{l}\text { (Income Levels in Social Enterprise- } \\
\text { Income Levels of Previous Work) }\end{array}$ & 0.658 & 0.362 & 0.469 \\
\hline & Employment & $\begin{array}{l}\text { Social Work } \\
\text { Participants' } \\
\text { Switch to } \\
\text { Similar } \\
\text { Work After } \\
\text { Contract } \\
\text { Expiration }\end{array}$ & $\left(\begin{array}{c}\text { Current Income Level for Work } \\
\text {-Income Level for Work Place } \\
\text { Before Social Enterprise } \\
\text { Employment) }\end{array}\right.$ & 0.129 & 0.193 & 0.126 \\
\hline & & $\begin{array}{l}\text { Income } \\
\text { Increase for } \\
\text { Vulnerable } \\
\text { Workers }\end{array}$ & $\begin{array}{l}\text { (Income Levels in Social Enterprise- } \\
\text { Income Levels of Previous Work) }\end{array}$ & 0.104 & 0.117 & 0.179 \\
\hline & Income & $\begin{array}{l}\text { Income } \\
\text { Increase of } \\
\text { Workers'/ } \\
\text { Service } \\
\text { Users' } \\
\text { Family } \\
\text { Through } \\
\text { Economic } \\
\text { Activities }\end{array}$ & $\begin{array}{l}\text { (The Number of Members Who } \\
\text { Became Economically Active by } \\
\text { Using the Service }) \\
\times(\text { Working Hours }) \\
\quad \times \text { (Minimum Wage })\end{array}$ & 0.023 & 0.067 & 0.079 \\
\hline \multirow{2}{*}{$\begin{array}{l}\text { Community } \\
\text { Contribution } \\
\& \\
\text { Government's } \\
\text { Budget } \\
\text { Reduction }\end{array}$} & \multirow[t]{2}{*}{$\begin{array}{l}\text { Community } \\
\text { Contribution }\end{array}$} & $\begin{array}{l}\text { Affordable } \\
\text { Social } \\
\text { Services }\end{array}$ & $\begin{array}{l}\left(\begin{array}{c}\text { Market Price of Social Service } \\
\text {-Price of Social } \\
\text { Service Provided by the } \\
\text { Company }\end{array}\right) \\
\times \text { Number of Service Provided }\end{array}$ & 0.057 & 0.127 & 0.093 \\
\hline & & $\begin{array}{l}\text { Free } \\
\text { Provision } \\
\text { of Social } \\
\text { Services }\end{array}$ & $\begin{array}{l}\text { (Applicable Market Price) } \times \\
\text { (Frequency of Service Provided) }\end{array}$ & 0.029 & 0.134 & 0.054 \\
\hline
\end{tabular}

Considering these results, in order to increase the value of social enterprise, it is necessary to make efforts to form social capital by raising the public's awareness of social value with efficient management through various evaluations of the emergence of various social enterprises and their performance. It is also advantageous to select a method of value measurement in connection with government policies. At present, the Korean government is trying to measure the value of social enterprises, and it is expected that detailed, more robust methods will be suggested through further research. In the future, the evaluation of social enterprises needs to be conducted together with the valuation of social enterprises that applied SROI, as SROI plays a key role in efficiently cultivating and managing social enterprises in Korea. And this research emphasises the need to better understand social enterprises as a multi-scholar and multi-dimensional organisation that includes a multi-faced mechanism of social, economic, and environmental community development, away from understanding social enterprises as a specific business model. 
This research has few limitations in spite of the encouraging and positive findings reported here. The model presented in this study has limitations in terms of accurately measuring the value of social enterprises by assessing them through return on investment (ROI), a commonly used and generic tool that was used to carry out of a financial analysis of social enterprises. Therefore, future research should proceed with making consistent efforts towards developing a new model that can properly judge these values while the positive externalities, which are the main characteristics of social enterprises, are highlighted. Although the possibility of generalisation is limited, this research does suggest an agenda for future research in this area and suggests further that the conceptual framework discussed here has a broader scope beyond Korea's context, as the findings and moot points enumerated in this study were derived from a wider international literature.

\section{Acknowledgements}

This study was supported by Woosuk University. We would like to humbly acknowledge Woosuk University for providing us the unique opportunity of carrying out this study.

\section{References}

1. Spall P, Zetlin D. Third sector in transition: a question of sustainability for community service organizations and the sector? Aust J Soc Issues. 2004;39(3):283-98.

2. Sobeck J, Agius E. Organizational capacity building: addressing a research and practice gap. Eval Program Plann. 2007;30:237-46.

3. Weerawardena JR, McDonald E, Mort GS. Sustainability of nonprofit organizations: an empirical investigation. J World Bus. 2009;45:346-56.

4. Furneaux C. Social procurement: Promoting the sustainability of nonprofit organizations through the transformation of economic, social and cultural capital. 1st Oikos Young Scholars Organization Academy 2011. Organizations and Cultural Sustainability. Oikos Foundation for Economy and Ecology. 2011:1-12.

5. Leviton LC, Herrea C, Pepper SK, Fishman N, Racine DP. Faith in action: capacity and sustainability of volunteer organizations. Eval Program Plann. 2006;29:201-7.

6. Moizer J, Tracey P. Strategy making in social enterprise: the role of pp. resource allocation and its effects on organizational sustainability. Syst Res Behav Sci. 2010;27:252-66.
7. Lee SH. Improvement of funding for social enterprise. Financ Focus. 2013;22(31):12-13.

8. Alter SK. Case studies in social enterprise: International experience. London: Routledge; 2002.

9. Borzage C, Defpirmu J. Conclusions: social enterprises in Europe: adversity of initiatives and prospects. In: Borzage C, Defourny J, editors. The emergence of social enterprise. London: Routledge; 2001.

10. Dees JD, Emerson J, Economy P. Enterprising nonprofit: A toolkit for social entrepreneurs. John Wiley and Sons; 2001.

11. OECD. Social enterprises, Paris: OECD (Report by Noya, A. \& Lecamp, G. for the OECD); 1999.

12. Alonso I, Garcia-Garcia J. Cooperatives versus corporates in the Spanish agricultural sector: non-parametric estimation of technical efficiency, Ann Estud Econ Empresariales. 2009;19:61-90.

13. Gwak SH. Performance analysis and tasks of certified social enterprise. Soc Enterp Res. 2009;2(1):37-65.

14. Gwak SH. Analysis of social enterprise certification in. Soc Enterp Res. 2010;2(1):135-65.

15. Gwak SH, Kim MH, Kang SH, Ryu, JR. Analysis of social enterprise performance in 2010. Ministry of Employment and Labor, Korean Social Corporate Development Agency; 2011.

16. Kim SY. Development and application of performance indicators for social enterprise. Local Gov Res. 2008;12(1):31-59.

17. Kim JH, Lee JK. Analysis of economic and social performance of social enterprises. Korean Public Adm Rev. 2012;24(4):1037-64.

18. Seon NH, Park NH. An analysis of factors influencing social and economic performance of social enterprise. Local Adm Res. 2011;15(2):141-64.

19. Moon BK. A comparative study on social enterprise evaluation and certification system in Korea and USA. Korea Policy Sci Inst. 2012;16(2):1-28.

20. Moon BK. Conceptual characteristics and performance evaluation of social enterprises-focused on comparative advantage between B-corporation types. Korea Local Autonomy Bull. 2012;24(4):187-214.

21. Lee YT. A study on the BSC model development of social enterprise. Soc Enterp Res. 2008;1(1):65-92.

22. Jang JJ. A study on the introduction of DEA model for evaluating the efficiency social enterprise management: focusing on the care and housework support business in $\mathrm{H}$ area. Corp Manag Res. 2010;17(2):179-91.

23. Cho YB. Value measurement: SROI (Social Return on Investment). Usage Guidelines, Social Enterprise Researcher; 2009.

24. The Roberts Enterprise Development Fund. Measuring impact: REDF workforce development outcome measurement; 2003. 
25. Hardzi-Miceva K. A supportive financing framework for social economy organizations. In: Noya A, Clarence E, editors. The Social Economy. Paris: OECD; 2007.

26. Rutzen D. Durham M, Moore D. Overview of NPO legislation in Central and East Europe. www.icnl.org; 2004.

27. Noya A, Clarence E. The social economy building inclusive economies. Paris: OECD; 2007.

28. Austin J, Stevenson H, Wei-Skillern J. Social and commercial entrepreneurship: same, different, or both? Entrepreneursh Theory Pract. 2006 January:1-22.
29. London M, Morfopoulos RG. Social entrepreneurship: how to start successful corporate social responsibility and community-based initiatives for advocacy and change. London: Routledge; 2010.

30. Lynch K, Walls J. Jr. Mission, Inc.: the practitioner's guide to social enterprise. San Francisco, CA: Berrett-Koehler; 2009.

31. Satty TL. The analytic hierarchy process. New York: McGraw-Hill; 1980. 